\title{
The Influence of Variable to Taxpayer Compliance Agency
}

\author{
Hairul Anam per ${ }^{1}$, Nurlia ${ }^{2}$ \\ ${ }^{\#}$ Economic Faculty, Balikpapan Universit, Indonesia \\ ${ }^{1}$ hairul@uniba-bpn.ac.id \\ ${ }^{2}$ nurlia@uniba-bpn.ac.id
}

\begin{abstract}
The population of this study is the taxpayer of the registered entity in the Tax Office. The sample of research is $\mathbf{1 0 0}$ respondents. The results showed that the Application of Modernization of Tax Administration System, the awareness of taxpayers have a significant positive influence on taxpayer compliance, while the financial condition has no significant influence on taxpayer compliance. Financial Condition cannot moderate the relationship between Application of Modernization of Tax Administration System to Taxpayer Compliance, and Financial Condition also cannot moderate the relationship between Taxpayer Awareness to Corporate Taxpayer Compliance.
\end{abstract}

\section{Keywords - application modernization, tax administration system, taxpayer awareness, financial condition taxpayer, taxpayer compliance.}

\section{INTRODUCTION}

Government revenue in domestic revenues and revenues receipts from abroad include loans and foreign aid. Government revenue derived from domestic revenues is tax. Taxes as a source of State revenue, the government continues to make efforts to increase tax revenue. One attempt to extend the subject of the tax or more often referred to as the taxpayer. Extensification is an effort to increase income tax article 1 verse 1 of [36] states that it is a mandatory contribution to the state owed by an individual or a legal entity with the same interests for the welfare of the people.

In the taxation levy in Indonesia currently embraces a system in which it is obliged to be given a trust to calculate itself the amount of tax payable, then cut by the other party, and pay a large tax already decided by another party, to be paid and reported to the Tax Office in accordance with provisions which have been stipulated in the applicable regulations. This system is one of the government's efforts to give confidence to the public widely against the transparency of taxation. The government believes this can increase the sense of obligatory responsibility towards taxation.
However the fact is different when the Minister of Finance recorded tax revenue in 2014 reached only 773.343 trillion or still far from the target in 2014 state budget of 1,072, trillion [7].

Data of the Directorate General of Taxes is able to collect tax realization of $94.37 \%$ in 2012 $835,255.12$ with realization of 2013 , realization of tax receipts amounting to $916,299.57$ from the state budget of $995,213.90$ with a percentage of $92.07 \%$. However, in 2014, the Directorate General of Tax only collects revenues of $773,343.68$ below from the 2014 APBN of $1,072,376.37$ with a percentage of $72.11 \%$. This situation is called Tax Shortfall in 2014 due to slowing economic growth, weakening imports, and falling prices on palm oil in International markets [7]. Aligned with the problems that occur to the level of taxpayer compliance, one of which is the corporate taxpayer in submitting the Notice, proven in 2014-2015, the Tax Office Pratama Balikpapan launching tax compliance level of the sector of business entities registered in the Tax Office Pratama Balikpapan experienced a significant decline in the delivery of the Notice.

Amidst the increasing burden of state revenue security and the low level of public confidence in the tax system, the government needs to undertake a comprehensive reform in taxation. Without a fundamental strategy, it is feared there will be a decrease in compliance pay taxes, so it can disrupt the stability and sustainability of state finances. One of the concrete steps taken by the Directorate General of Taxation to optimize the funds from the tax sector by conducting a program change (change program) or reform of the tax administration system that can briefly be called modernization. Modernization in the field of taxation is marked by the establishment of the vision of the Directorate 
General of Taxes is a model of public service that organizes systems and management of world-class taxation is trusted and proud community.

One of the changes made in the modernization of tax administration system is to improve the quality of service by improving the business process that is utilizing business process and information and communication technology by applying transparent and accountable good governance, one of them by applying electronic system or e-system [8]. Implementation of e-system is a tax administration system that uses modern technology today. Esystem is expected to provide convenience and convenience for taxpayers in preparing for taxation duties performed electronically through a real time online system to the Directorate General of Taxes via the internet on the website of the Directorate General of Taxes or through Application Providers that have been appointed by the Directorate General of Tax. The application of modernization of the tax system is expected to increase awareness of taxpayer compliance in performing its tax obligations by providing convenience, convenience, effective and efficient in the delivery of tax administration. Taxpayer awareness is a condition when the taxpayer has known, understood and implement the provisions of taxation correctly. With the awareness of the taxpayer and supported by the implementation of e-system that provides easiness in tax administration, taxpayers are expected to perform the obligation to pay taxes voluntarily without any coercion. Directorate General of Taxes states that raising taxpayer awareness is the main challenge of DGT, because to build awareness and voluntary care of taxpayers need to underlie the idea that the awareness of paying taxes must come from themselves and of course the Directorate General of Taxation needs to make changes or in other words to reform the service in order to provide awareness and improve taxpayer compliance (tax.go.id/increase awareness). Reform or often called modernization is the right strategy to increase awareness of taxpayers in order to achieve the target of tax revenue realization. In making tax payments, taxpayers, especially the body must pay attention to the company's financial condition. Financial condition is the company's financial capability as reflected by its cash flow.
From the research that examines the relationship between taxpayer compliance with some variables that can state that the relationship can be moderated by several variables such as financial condition, indicating that the financial condition can moderate the relationship of one's commitment. The implication is that the burden of a company that is the responsibility of the company may moderate the firm's commitment to pay its obligations including tax payments.

Article 1 of [36] concerning the definition of taxation reads that tax is a compulsory contribution to a country owed by an individual or a coercive body under the Act, without being directly compensated and used for the purposes of the state for the maximum amount, great prosperity of the people [1], taxes are contributions to the state (which may be enforced) owed by those obliged to pay according to the rules, with no immediate return, which may be appropriately appointed, and whose use is to finance general expenses relating to the task of the state to organize the government. Taxes are achievements to governments owed through common norms, and which can be imposed, without any contracts [1].

Reference [11] argues that taxes are unilaterally enforced achievements by and owed to the authorities (according to norms he sets out in general), in the absence of contracting and solely used to cover general expenses. Reference [15] said tax is the contribution of the people to the state treasury under the law (which can be enforced) with no direct lead service (contra).

Reference [11], [15] offer tax collection system as official assessment system, self assessment system and with holding system, namely: The Official Assessment System is an authorized tax collection system to determine the amount of tax payable by the taxpayer according to the applicable tax laws. Self assessment system is a tax collection system that gives authority to the taxpayer to determine for themselves the amount of tax payable. Taxpayers calculate, calculate, pay and self-report the amount of tax payable.

With holding system is a tax collection system that authorizes third parties (not tax authorities and not taxpayers concerned) to determine the amount of tax payable by the taxpayer. 
As a form of appreciation for public participation, the Directorate General of Tax always strives to provide efficient, professional and fair services in the administration of tax administration. Since 2002, the Directorate General of Taxation has launched a tax reform or reform program commonly referred to as modernization, in accordance with the issuance of [23]. The soul of this modernization program is the implementation of good governance, namely the implementation of transparent and accountable tax administration system, by utilizing reliable and upto-date technology information system. Understanding of the modernization of taxation is one of the fundamental changes made by the government in the field of taxation. Modernization of tax administration system aims to increase one's independence in financing development, in the sense to improve taxpayer compliance. It is intended that the government wants to more direct the potential sourced from within the country, especially by increasing state revenues through the tax sector.

Reference [30] discusses the implementation of modern tax administration system is a positive indication from the government to jointly with the taxpayer society manage tax effectively and efficiently. In the modernization that utilizes information technology, the Directorate General of Taxes roll out the application of tax administration using e-system. E-system is one of the modernization of taxation that facilitates the administration of taxation, using technology and delivery of administration through the on-line system. E-system of taxation is made in the hope to facilitate taxpayers to carry out its tax obligations. E-system can be divided into several types, eregistration and e-filing.

Reference [11] argues e-registration is one of the implementation of e-system that facilitates registration of Taxpayer Identification Number (NPWP) on-line based on technology. Registration of Taxpayer Identification Number on-line facilitates taxpayer in making NPWP, without having to come directly to the nearest Tax Office. Taxpayer Identification Number is a means of tax administration that has a function as a selfidentification or can be said to be the identity of the taxpayer and also maintain compliance in tax payments that are supervised by the part of a tax administration. Someone who already has NPWP will be more easily detected by the Directorate General of Taxes.

Reference [4] describes e-filing is an annual electronic delivery notification (SPT) which is conducted on-line in real time through the website of Directorate General of Taxes at (www.pajak.go.id) or provider Application Services or Application Service Provider. The use of e-filing has been regulated by [20], where the use of e-filing is the way of delivering the SPT on-line with forms 1770S and 1770SS. The application of e-filing as a step in the modernization of the tax system in Indonesia is expected to provide excellent service to the public so as to improve the ease of reporting taxation and improve taxpayer compliance.

In a large Indonesian dictionary of 2015, conscious words have the meaning of convergence and understanding, in the sense that consciousness is a state of understanding of things felt or experienced by a person will be the values contained in man about the existing law [13]. Literally, consciousness is the same as introspection. Reference [12] describes the motive of consciousness is the process of thinking that is done by an individual to a situation, in obligations or decisions.

In the Indonesian language dictionary 2015, the word condition has a state meaning [13]. As for the word finance which means something that is related to money, in other words the financial condition is a financial condition of a person or organization seen in the records of his financial statements.

Reference [29] states financial statements are prepared for the purpose of providing information pertaining to financial conditions, performance and a change in the financial position of the enterprise that benefit a large number of users in economic decision-making. In addition to these objectives, financial statements also show what has been done by the management or describe the responsibility. Meanwhile, liquidity is an ability owned by the company in fulfilling its short-term obligations. In other words, it can be said that the definition of liquidity in the mean as a comparison between current assets with current liabilities. In this case the company should pay attention to whether the 
company at any time can meet the payments that are the responsibility of the company. A company can fulfil its financial obligations if the company makes a profit, so that the company is able to demonstrate the ability of the company to meet all financial obligations and the company's financial condition can be viewed in the cash flow statement, useful for assessing the company's need to use the cash flows [29].

Reference [13] obedient which became the basic word of obedience, meaningful obedience, always submissive. So taxpayer compliance can be interpreted as submissive, obedient and obedient taxpayer in implementing taxation rights and obligations in accordance with applicable laws and regulations. Reference [17] defines taxpayer compliance are tax compliance in its most simple form is the relative taxpayer comply with the tax law. However, like many such concepts, the meaning of compliance can be seen as a comparative study of the results of the society as reflected in the tax police.

Based on the definition of taxpayer compliance above, it can be concluded that compulsory compliance is compulsory taxpayer and discipline in implementing the rights and obligations of taxation in accordance with the provisions of applicable tax laws.

There are six hypotheses as below:

- H1: The application of modernization of tax administration system has a positive effect on corporate taxpayer compliance in Tax Office Pratama Balikpapan.

- H2: Taxpayer awareness has a positive effect on taxpayer compliance in Tax Office Primary Balikpapan.

- H3: The financial condition has a positive effect on taxpayer compliance in Tax Office Primary Balikpapan.

- H4: The application of modernization of tax administration system, Taxpayer Awareness, Financial Condition simultaneously effect to taxpayer compliance

- H5: Financial conditions moderate the relationship between the modernization of the tax administration system to taxpayer compliance bodies in the Tax Office Pratama Balikpapan.

- H6: Financial conditions moderate the relationship between the taxpayer's awareness of taxpayer compliance at the Tax Office Primary of Balikpapan City.

\section{METHODS}

This research is conducted quantitatively that is research which is used to research in certain population or sample and data collection using research instrument, with descriptive research design, such as knowing how much relation of a variable [32].

The population is a generalization region consisting of objects or subjects that have certain qualities and characteristics determined by the researchers to be studied and then taken the conclusion. Population in this research is corporate taxpayer. Whereas, the sample is part of the number and characteristics possessed by a population. The sampling technique used in this research is incidental sampling [32]. To decide the sample in this study, Slovin formula is applied [35], which is as many as 100 samples.

\section{A. Hypothesis testing}

1) Multiple Linear Regression: multiple linear regression is an observation caused not only by one variable, but by several or even many variables. Here is the multiple linear regression equation [35]:

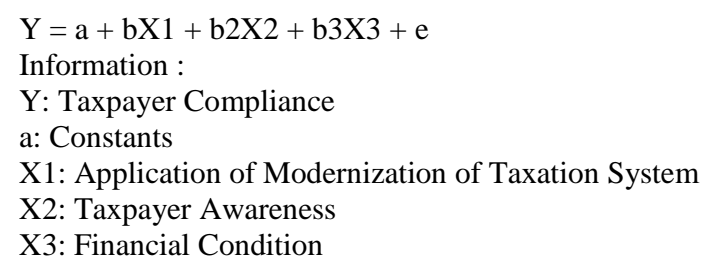

2) Moderated Regression Analysis (MRA): Moderated Regression Analysis (MRA) used an analytical approach that maintains the integrity of the sample and is the basis for controlling the effect of moderating variables [10]. Here is the regression equation to determine the type of variables moderated by the research regression model as follows:

Regression Model I: Y $=\mathrm{a}+\mathrm{b} 1 \mathrm{X} 1+\mathrm{b} 2 \mathrm{Z} 1+\mathrm{b} 3 \mathrm{X} 1 * \mathrm{Z} 1+\mathrm{e}$ Regression Model II: $\mathrm{Y}=\mathrm{a}+\mathrm{b} 1 \mathrm{X} 2+\mathrm{b} 2 \mathrm{Z} 1+\mathrm{b} 3 \mathrm{X} 2 * \mathrm{Z} 1+$ e

Information :

Y: Taxpayer Compliance

a: Constants

X1: Application of Modernization of Taxation System

X2: Taxpayer Awareness 
Z1: Financial Condition

X1 * Z1: Financial Condition Moderator Modernization SystemPerpajakan

$\mathrm{X} 2 * \mathrm{Z} 1$ : Financial Condition Moderating Taxpayer Awareness

\section{RESULTS}

\section{A. Validity test}

The criteria used in determining the validity of the question used in this study by adjusting the number of results of the questionnaire so that it can $\mathrm{r}$ table $=0.195$. If $\mathrm{r}$ count is greater than $\mathrm{r}$ table and the value of $r$ is positive, then the statement item is considered valid. From the Validity test obtained each variable is Valid, $r$ count is greater than $r$ table.

\section{B. Test Reliability}

Test reliability is done to determine whether the measuring tool that has been designed in the form of questionnaires reliable, to see whether or not a measuring tool used statistical approach, namely through the coefficient of reliability and if the reliability coefficient $>0.60$ then the whole question is declared reliable.

\section{Coefficient of Determination}

Coefficient Determination known by the value of R Square obtained by 0.364 or $36.4 \%$. This figure provides evidence that corporate taxpayer compliance is influenced by the application of modernization tax administration system, taxpayer awareness and financial condition of $36.4 \%$ while the rest of $63.6 \%$ influenced by other variables outside this study.

\section{Hypothesis testing}

The application of modernization of tax administration system (X1) to taxpayer compliance (Y) has a significant level of $0.015<0.05$, proving the application of modernization tax administration system has a significant effect on taxpayer compliance bodies. This research is similar to research conducted by [14] which states the application of modernization of tax administration system to taxpayer compliance agency. The better the application of modernization in the tax administration system, the higher the level of taxpayer compliance. The application of modernization of tax administration system has an effect on taxpayer compliance because it gives easiness in the delivery of tax administration so that it will improve taxpayer compliance.

\section{IV.DISCUSSION}

Taxpayer awareness (X2) on taxpayer compliance $(\mathrm{Y})$ shows that the consciousness of taxpayers has a significant level of $0.000<0.05$, proving that the consciousness of taxpayers has a significant influence on taxpayer compliance. The results of this study is similar to the research conducted by [33] which states the consciousness of taxpayers have a significant effect on corporate taxpayer compliance. The higher the awareness of the taxpayer, the higher the taxpayer compliance. Awareness of taxpayers affect taxpayer compliance because if the taxpayer aware of the importance of his pay taxes for the development of the nation so that will be able to improve taxpayer compliance.

The company's financial condition (Z) on corporate taxpayer compliance $(\mathrm{Y})$ shows that the company's financial condition has a significant level of $0.856>0.05$, proving that the financial condition has no significant effect on corporate taxpayer compliance. The results of this study are different from the research [18] states that the financial condition affect the compliance of corporate taxpayers. The company's financial condition has no significant effect on taxpayer compliance because the company will still carry out its tax obligation even though the company's financial condition is unstable although it has to sacrifice the company's cash flow because the taxes arise as a result of an activity that result in taxes.

Between the results obtained significance value $0.000<0.05$ which means that the implementation of the modernization of tax administration system, taxpayer awareness of and financial condition together significantly influence the compliance of tax agency. The results of this study support research conducted by [14. [18], [33].

Interaction test result between modernization of tax administration system with financial condition $(\mathrm{X} 1 * \mathrm{Z})$ shows interaction result has value of significant level equal to $0,859<0,05$, proves that financial condition cannot moderate relationship between applying modernization of tax 
administration system to taxpayer compliance body. The results of this study differ from the research [2]-[3], [16] state that the financial condition can moderate the relationship of the tax system to taxpayer compliance. Financial condition cannot moderate the relationship between $\mathrm{X} 1$ to $\mathrm{Y}$ because if the unstable financial condition does not affect the use of modernization tax administration system that can impact on taxpayer compliance level.

Between the results obtained significance value $0.000<0.05$ which means that the implementation of the modernization of tax administration system, taxpayer awareness of and financial condition together significantly influence the compliance of tax agency. The results of this study support research conducted by [14], [18], [33].

Interaction test result between modernization of tax administration system with financial condition $(\mathrm{X} 1 * \mathrm{Z})$ shows interaction result has value of significant level equal to $0,859<0,05$, proves that financial condition cannot moderate relationship between applying modernization of tax administration system to taxpayer compliance body. The results of this study differ from the research [2]-[3], [16] state that the financial condition can moderate the relationship of the tax system to taxpayer compliance. Financial condition cannot moderate the relationship between $\mathrm{X} 1$ to $\mathrm{Y}$ because if the unstable financial condition does not affect the use of modernization tax administration system that can impact on taxpayer compliance level.

The result of interaction test between taxpayer's consciousness and financial condition (X2 * Z) shows interaction result has significant level value equal to $0,673>0,05$, proves that financial condition cannot moderate the relation between taxpayer awareness to taxpayer compliance. The results of this study differ from research [2]-[3], [16] stating that financial conditions can serve as moderating variables. Financial condition cannot moderate the relationship between $\mathrm{X} 2$ to $\mathrm{Y}$ because if the unstable financial condition does not affect the awareness of taxation that can improve taxpayer compliance.

The result of interaction test between taxpayer's consciousness and financial condition (X2*Z) shows interaction result has significant level value equal to $0,673>0,05$, proves that financial condition cannot moderate the relation between taxpayer awareness to taxpayer compliance. The results of this study differ from research 2]-[3], [16] state that financial conditions can serve as moderating variables. Financial condition cannot moderate the relationship between $\mathrm{X} 2$ to $\mathrm{Y}$ because if the unstable financial condition does not affect the awareness of taxation that can improve taxpayer compliance.

\section{CONCLUSIONS}

The application of modernization of tax administration system affect the compliance of corporate taxpayers. The application of modernization of tax administration system has an effect on taxpayer compliance due to giving easiness in the delivery of tax administration so that it will improve taxpayer compliance.

Taxpayer awareness affects the compliance of corporate taxpayers. Awareness must affect taxpayer compliance because taxpayers are aware of their tax obligations primarily to build the State. The company's financial condition affects taxpayer compliance is not significant, because if the financial condition of a company is not stable, then the company will still carry out its tax obligations.

That the application of modernization of tax administration system, awareness of taxpayers and financial condition affect taxpayer compliance. Based on the moderating interaction test that the financial condition cannot be said as a moderating variable that can strengthen or weaken the relationship between variables that is the application of modernization of tax administration system to taxpayer compliance agency.

\section{REFERENCES}

[1] Agoes, Sukrisno. (2013). Tax accounting. Jakarta: Salemba Four.

[2] Allabede, Jhames. (2013). Does Taxpayer's Financial Condition Moderate Determinants of Tax Compliance Behavior? Evidance From Nigeria. British Journal of Economics and Management Sciences, ISSN 2048-125X.

[3] Aryobimo, Tri Putut. (2012). The Effect of Taxpayers' Perception on the Quality of Fiscal Services on Taxpayer Compliance with Taxpayer Financial Condition and Risk Preference as Moderating Variables. Diponegoro Journal of Accounting, 1 (2).

[4] Diana, Anastasia. (2014). Taxation-Theory and Current Regulations. Yogyakarta: ANDI Offset.

[5] DGT, (2012). Evaluation of Tax Receipts Year 2012. Taken from http://www.pajak.go.id/content/penerimaan-pajak-dalam-negeri-20092012 accessed on the date of August 29, 2015. At 20:05 pm. 
[6] DGT, (2013). Realization of Tax Receipts Year 2013. Taken from http://www.pajak.go.id/content/penerimaan-pajak-2013 accessed on the date of 29 August 2015. At 20:15 pm.

[7] DGT, (2014). Tax Receipts of the Year 2014. Taken from http://www.pajak.go.id/content/penerimaan-pajak-2014. Retrieved on 29th August 2015. At 20.30 Wita.

[8] DGT, (2007). Annual_Report Modernization of Tax Administration. Taken from http://www.pajak.go.id/sites/default/files/Annual_Report\%202007.pdf. Retrieved on August 27th. At 11:05 pm.

[9] DGT, (2015) Building Consciousness and Voluntary Concern of Taxpayers. Taken from http://www.pajak.go.id/content/building-ofconsciousness-and-current-representation-web- Retrieved on 01 September 12.45 Wita.

[10] Ghozali, Imam. (2009). Multivariate Application with SPSS Program. Semarang: UNDIP Publishing Agency.

[11] Halim, Abdul. (2014). Taxation, Concepts, Sample Applications and Case Studies. Jakarta: Salemba Four

[12] Ikhsan, Arfan. (2014). Behavioral Accounting. Jakarta: Salemba Empat.

[13] Big Indonesian Dictionary, (2015). http://kbbi.web.id accessed on 20th september 2015. At 7:20 pm

[14] Lusiana, (2013). The Effect of Tax Knowledge and Modern Tax Administration System on Taxpayer Compliance. Journal of Accounting Research, V (2). ISSN: 2086-0447.

[15] Mardiasmo. (2011). Taxation. Yogyakarta: ANDI Offset.

[16] Mekonen, Teshome. (2015). The Moderating of Financial Condition on Tax Compliance. Behavior: Evidence From Mekelle City. Research Journal of Finance and Accounting. ISSN: 2222-1697.

[17] Mukhlis, Imam. (2012). Economic Dimension of Taxation in Economic Development. Jakarta: Achieve Success Asa.

[18] Mustikasari, Elijah. (2007). Empirical Study on Taxpayer Compliance Agency in Industry Management in Surabaya. Procedia-Accounting National Symposium X: 1-42.

[19] Regulation of the Directorate General of Taxes Number KEP-36 / PJ / 2013 concerning the provisions of the delivery of tax administration and tax payment electronically.
[20] Regulation of the Directorate General of Taxes No. KEP 06 / PJ / 2014 on the use of online-based administrative e-filing.

[21] Regulation of the Minister of Finance No. 475 / KMK.04 / 1996 on Income Tax Income 15.

[22] Regulation of the Minister of Finance Number 164 / KMK.03 / 2002 concerning Income Tax Income Tax 24.

[23] Regulation of the Minister of Finance No. 192 / KMK.03 / 2007 on taxpayer compliance requirements.

[24] Regulation of the Minister of Finance Number 251 / PMK.03 / 2008 concerning Income Tax Income Tax 23.

[25] Regulation of the Minister of Finance No. 208 / PMK.03 / 2009 concerning Income Tax Income Tax 25

[26] Regulation of Directorate General of Taxation Number 57 / PJ / 2009 concerning the provisions of Tax Regulation Penghasilan PPh 21.

[27] Regulation of the Minister of Finance Number 82 / PMK.03 / 2009 concerning Income Tax Income Tax 26.

[28] Regulation of the Minister of Finance Number 224 / PMK.011 / 2012 concerning Income Tax Income Tax 22.

[29] Prastowo, Dwi. (2014). Financial Statement Analysis. UPP STIM YKPN: Third Edition.

[30] Purwono, Herry. (2014). Fundamentals of Taxation \& Tax Accounting. Jakarta: Erlangga.

[31] Sambodo, Agus. (2015). Taxes In Business Entities. Jakarta: Salemba Empat.

[32] Sugiyono, (2014). Qualitative Quantitative Research Methods $R \&$ \& Bandung: Alfabeta

[33] Supadmi, Ni, (2014). The Effect of Tax Inspection, Taxpayer Awareness, Service Quality Against Corporate Taxpayer Compliance Level. E-Journal of Accounting, Udayana University. ISSN: 23028556.

[34] Tjahjono, Achmad. (2005). Taxation. YKPN Corporate Management Academy: Third Edition.

[35] Umar, Husein. (2011). Research Methods for Thesis and Business Thesis. Jakarta: Rajawali Pos.

[36] Law. (2009). No. 16 on General Provisions and Tax Procedures. Jakarta. 